\title{
International approaches to the hydraulic control of surface water runoff in mitigating flood and environmental risks
}

\author{
Bridget Woods Ballard ${ }^{1}$, Helen Udale-Clarke ${ }^{1, a}$, Richard Kellagher ${ }^{1}$, Vivian Dou ${ }^{2}$, David Powers ${ }^{3}$, Aurélie Gerolin ${ }^{4}$, \\ Anthony McCloy ${ }^{5}$ and Theo Schmitt ${ }^{6}$ \\ ${ }^{1} H R$ Wallingford Ltd, Howbery Park, Wallingford, OX10 8BA, UK \\ ${ }^{2} H R$ Wallingford Ltd, China \\ ${ }^{3} \mathrm{HR}$ Wallingford Ltd, USA \\ ${ }^{4}$ Cerema, France \\ ${ }^{5}$ McCloy Consulting, UK \\ ${ }^{6}$ University of Kaiserslautern, Germany
}

\begin{abstract}
This paper compares and contrasts a number of international approaches to the hydraulic control of surface water runoff from new development and redevelopment, known as sustainable drainage systems (SuDS) or low impact development (LID). The paper provides a commentary on the progress and current status of national standards for SuDS in the UK to control the frequency, flow rate and volume of runoff from both frequent and extreme rainfall events, and the best practice design criteria presented in the revised UK CIRIA SuDS Manual, published in November 2015. The paper then compares these design criteria and standards with those developed and applied in China, USA, France and Germany and also looks at the drivers behind their development. The benefits of these different approaches are assessed in the context of flood risk mitigation, climate resilience and wider environmental protection objectives, including water quality, morphology and ecology. The paper also reviews the design approaches promoted by the new SuDS Manual and internationally for delivering additional benefits for urban spaces (such as recreation, visual character, education and economic growth) through multi-functional urban design.
\end{abstract}

\section{Introduction}

Approaches to the management of surface water runoff from urban development are undergoing a period of significant change. The efficacy and sustainability of traditional piped solutions is being questioned as climate, population and environmental pressures put the economics of such an approach in question. The need to take a more integrated approach to water management - maximising its value through all stages in the water cycle - has never been more important and surface water runoff is a crucial element of this.

Global water shortages mean that the intrinsic 'value' of runoff from rainfall is becoming increasingly understood and recognised in decision-making. Drivers for the use of runoff to meet non-potable supply needs (including toilet flushing, landscape and horticulture, building cooling water, vehicle cleansing etc) increase as the availability and security of water resources decrease and the costs rise. The heat stress associated with dense urban areas is being exacerbated by rising global temperatures and, with the density of urban populations rising rapidly, urban designers are looking to vegetated surfaces and water storage zones to provide essential cooling to ensure urban 'liveability' and community health under future climatic conditions.
In many places, more intense rainfall is another outcome of observed climatic changes and, combined with increasing urban impermeability levels (often described as 'urban creep'), leads to the design standard of service of existing sewerage infrastructure often being lower than expected and the risk of surface water flooding therefore higher. The cost of enhancing capacity of this infrastructure is often prohibitive, so new solutions to reducing surface water loadings from existing areas and minimising loadings from new development zones are needed. The adaptability of systems, in the face of climate and urbanisation change, is also a key attribute (Ashley et al, 2015).

International environmental protection regulations (eg EU Water Framework Directive) have developed in response to recognition of the urgent need to reverse the deterioration in quality of surface waters and protect their functionality now and for future generations. Urban diffuse pollution has been identified as a significant influence on quality and morphology principally resulting from the uncontrolled discharge of surface runoff (normally contaminated with a suite of urban surface pollutants) and spills from combined sewer overflows.

These drivers exist for both developed and developing countries and have triggered the need to

${ }^{\mathrm{a}}$ Corresponding author: h.udale-clarke@hrwallingford.com 
consider drainage system designs that mitigate the impact of the development on runoff characteristics; reduce the risk of urban surface water flooding from intense rainfall events; use runoff as a non-potable source of water, trap and/or treat pollution prior to discharge; avoid mixing surface water with foul sewage; and deliver and enhance high value amenity and biodiversity assets within developments.

This paper reviews a range of current international approaches to surface water management and how they are changing; and takes a look at the drivers, new objectives and design criteria for drainage design in a number of different countries.

\section{United Kingdom}

The following sections describe the universally adopted industry guidance, and then the regulatory and policy environment in each of the regions of the UK. There are also a number of relevant British Standards (nonstatutory) including BS8582: 2013, BS 8515: 2009 and BSEN 752: 2008that provide additional support.

\subsection{The new edition of the UK SuDS Manual (Woods Ballard et al, 2015)}

The new edition of the SuDS (sustainable drainage systems) Manual was published in November 2015 and, in the UK, will support the implementation of recommended national standards and regulations set independently by the devolved administrations and any local requirements specified by planning bodies. In the 2007 version of the Manual, SuDS were described as 'drainage systems developed in line with the ideals of sustainable development'. In the 2015 version, the description is 'systems designed to maximise the opportunities and benefits we can secure from surface water management'.
The guidance recognises that the types and scale of benefits that can be achieved by any system will be dependent on the site specific characteristics, development context and local objectives but will fit broadly into four categories: water quantity, water quality, amenity and biodiversity. These are referred to in the Manual as the four pillars of SuDS design and each of these pillars has a design objective, as presented in Figure 1.

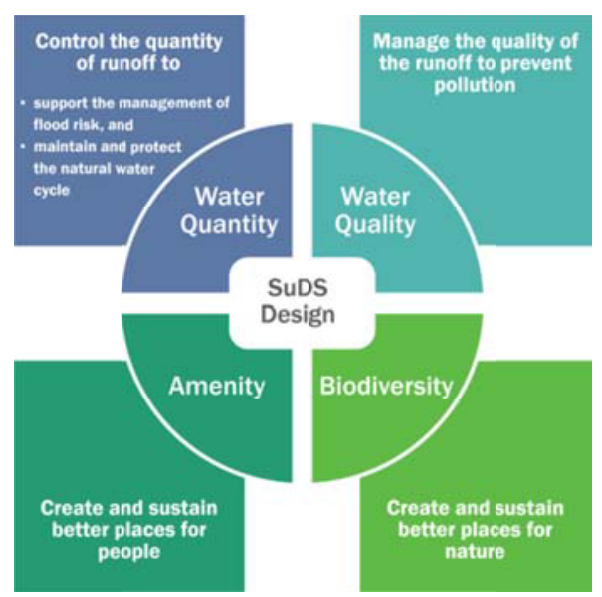

Figure 1 The design objectives of SuDS (Woods Ballard et al, 2015)

In order to deliver these design objectives, the Manual suggests a number of key design criteria which should be considered at every site (see Table 1). The water quantity and water quality criteria are likely to be the main design drivers and these will normally be supported by standards (expected levels of service) for the system. However, maximising delivery of amenity and biodiversity criteria will often deliver on a range of other required planning outcomes/objectives for the site.

\begin{tabular}{|c|c|c|}
\hline & Design criteria & Design standards \\
\hline $\begin{array}{c}\text { Water } \\
\text { quantity }\end{array}$ & $\begin{array}{l}\text { 1. Use surface water runoff as a resource } \\
\text { 2. Support the management of flood risk in the receiving } \\
\text { catchment } \\
\text { 3. Protect morphology and ecology in receiving surface waters } \\
\text { 4. Preserve and protect natural hydrological systems on the site } \\
\text { 5. Drain the site effectively } \\
\text { 6. Manage on-site flood risk } \\
\text { 7. Design system flexibility/adaptability to cope with future } \\
\text { change }\end{array}$ & $\begin{array}{l}\text { - } \quad \text { Control runoff volumes for frequent events } \\
\text { - } \quad \text { Control runoff volumes for extreme events } \\
\text { - } \quad \text { significance to morphological protection } \\
\text { Control peak runoff rates for events of } \\
\text { significance for flood risk management } \\
\text { - } \begin{array}{l}\text { Design drainage system to a fixed standard } \\
\text { of service }\end{array} \\
\text { - Manage exceredance flows from the } \\
\text { drainage system to mitigate flood risk }\end{array}$ \\
\hline $\begin{array}{l}\text { Water } \\
\text { quality }\end{array}$ & $\begin{array}{l}\text { 1. Support the management of water quality in the receiving } \\
\text { surface waters and groundwaters } \\
\text { 2. Design system resilience to cope with future change }\end{array}$ & $\begin{array}{l}\text { - } \quad \text { Control runoff volumes for frequent events } \\
\text { - } \quad \text { Treat runoff to mitigate pollution risks }\end{array}$ \\
\hline Amenity & $\begin{array}{l}\text { 1. Maximise multi-functionality } \\
\text { 2. Enhance visual character } \\
\text { 3. Deliver safe surface water management systems } \\
\text { 4. Support development resilience/adaptability to future change } \\
\text { 5. Maximise legibility } \\
\text { 6. Support community environmental learning } \\
\end{array}$ & \\
\hline Biodiversity & $\begin{array}{l}\text { 1. Support and protect natural local habitats and species } \\
\text { 2. Contribute to the delivery of local biodiversity objectives } \\
\text { 3. Contribute to habitat connectivity } \\
\text { 4. Create diverse, self-sustaining and resilient ecosystems }\end{array}$ & \\
\hline
\end{tabular}

Table 1 Design criteria for SuDS (Woods Ballard et al, 2015) 
It is emphasized that many of these criteria are interdependent or cross-cutting, and that in order to maximise opportunities and the associated benefits, the criteria should be considered at an early stage and fully integrated into the surface water management and urban design process. In so doing, it is then possible to ensure that the scheme is truly multi-functional and delivers the highest return for the developer and for the community who will live there.

\subsection{England: Drivers and Policy}

The independent review into the causes of the 2007 floods (Pitt, 2008) concluded SuDS were an effective way to reduce the risk of surface water flooding and recommended that the government implement measures to increase uptake of SuDS alongside the removal of the automatic right of connection of developers to the local sewerage network. Schedule 3 of the Flood and Water Management Act 2010 made the delivery of SuDS to meet a set of statutory National Standards a requirement for all new development, and established SuDS Approving Bodies within Lead Local Flood Authorities to approve and adopt the systems post construction. After two phases of consultation, this approach raised too many challenges for the English Government and a decision was made instead to incorporate SuDS delivery within the planning process (DCLG, 2014) and to include non-statutory policy standards (Defra, 2015) within the National Planning Practice Guidance (DCLG, 2015). The proposed benefits of the revised approach are:

- the strengthening of the planning regime - enabling decision-makers to give increased weight to the provision and maintenance of SuDS as a material planning consideration alongside e.g. transport infrastructure, density of development etc;

- the alignment of drainage delivery with development design - facilitating and promoting joined up approaches to the management and use of surface water on developments - between urban and landscape designers, architects and building engineers, ecologists and drainage designers;

- improved efficiency and reduced delivery risks associated with approvals from multiple bodies within the local authority system.

However, there are a significant number of risks to widespread SuDS implementation, yet to be addressed:

- there is now no standard body responsible for taking ownership of SuDS in perpetuity. This is contrary to Pitt's recommendations regarding the benefits of ownership by either the local authorities or water companies - both offering integrated surface water management benefits above and beyond service management;

- the automatic right to connect for developers remains (although is being re-debated at the time of publication);

- the set of non-statutory standards within the planning guidance address only hydraulic control of surface water discharges (peak flow control for 1 and 100 year return period events; volume control for the 100 year, 6 hour event; pumping only in exceptional circumstances); the standard of service and management of risk of flooding from the drainage system itself; and structural integrity of the system and adjacent or connected infrastructure - leaving the planning authority to make any requirements for water quality protection, amenity or biodiversity a site-specific condition of planning;

- the associated guidance (Lasoo, 2015) requires SuDS only where they are not more expensive than meeting current (i.e. traditional) drainage requirements.

\subsection{Wales: Drivers and Policy}

On 5 January 2016 the Welsh Government published recommended non-statutory standards for SuDS in Wales (Welsh Government, 2016). In contrast to the English standards, the standards for Wales deal with the runoff destination hierarchy (recommending that rainwater harvesting is given early consideration), the control of runoff for frequent rainfall events to protect the quality and morphology of receiving surface waters, and the objectives of maximising amenity and biodiversity benefits for the development site and wider environment - as well as the objectives of hydraulic control and onsite flood risk management, constructability, maintainability and structural integrity.

The Welsh Government has recognised that a SuDS approach to surface water drainage will contribute to the realisation of the well-being goals within the framework of the Future Generations (Wales) Act - by supporting a more prosperous, resilient, healthier, cohesive and globally responsible Wales into the future. The Welsh Government has stated that their next steps will be to work with stakeholders to identify the best way to embed the SuDS approach in all new developments in Wales, as set out in their Water Strategy published in 2015 possibly by commencing Schedule 3 of the Flood and Water Management Act 2010 for Wales independently of England. This would require new developments to manage surface water using the SuDS approach, with systems designed and built in accordance with a set of statutory standards and it would also provide a framework for their approval, adoption and ongoing maintenance.

\subsection{Scotland: Drivers and Policy}

In many ways, the development and application of SuDS in Scotland has led the way for the rest of the UK, with enabling legislation in place at an earlier stage than in England and Wales - although the primary focus in Scotland has been water quality protection. In 2003, the Water Environment and Water Services (Scotland) Act (WEWS) was implemented to deliver the requirements of the EU's Water Framework Directive. This was followed in 2005 by the Water Environment (Controlled Activities) Regulations under which there is a generalrequirement for new developments (except for single dwellings or discharges to coastal waters) with surface water drainage systems discharging to the water environment that such discharges will pass through SuDS with all reasonable steps being taken to ensure protection of the water environment. SEPA's guidance on designing drainage systems to meet the regulatory requirements for water 
quality protection are set out in their regulatory method (SEPA, 2014). The WEWS regulations also introduced new provisions into the Water (Scotland) Act 1980 and the Sewerage (Scotland) Act 1968 dealing with construction standards (specified in Sewers for Scotland (WRc, 2015) and owndership conditions for the adoption by Scottish Water of privately constructed water or sewerage, including drainage, infrastructure. Requirements for the hydraulic control of surface water runoff are not regulated like water quality and are generally set by local authorities. However, the Sustainable Urban Drainage Scottish Working Party has recently published the Water Assessment and Drainage Assessment Guide (SUDSWP, 2016)). This is intended to help guide those involved in the installation of water and drainage infrastructure (both new and retrofitting) through the necessary stages to obtain relevant permissions and comply with standards and policies; hydraulic requirements are specified in this document and mirror those established by the SuDS Manual.

\subsection{Northern Ireland: Drivers and Policy}

In Northern Ireland (NI), requirements for controlling the rate and volume of runoff from new development are inferred by Planning Policy PPS15 (NI DoE, 2014) where it is stated that 'new development and re-development must not cause increased risk of flooding elsewhere'. In practice this means that greenfield sites must maintain greenfield runoff rates and redevelopment sites must not increase runoff rates from the pre-redevelopment peak rates of discharge. For greenfield sites, the standing advice from the DARD Rivers Agency is that allowable runoff rates should be fixed at $10 \mathrm{l} / \mathrm{s} / \mathrm{ha}$.

Where the drainage scheme is offered up for adoption to NI Water, the requirements specified in Sewers for Adoption Northern Ireland (WRc, 2010) apply and provision must be made to accommodate a climate change factor which is defined as the addition of $10 \%$ to rainfall intensities. Flow rates for surface runoff also need to be controlled to a rate which the recieving sewer network has capacity for. At present, a significant number of the NI sewerage systems are already at capacity, driving more strict implementation of the requirement to significantly attenuate flow rates of surface runoff leaving sites. NI Water is currently in the process of updating the document to reflect the recent changes to the Water \& Sewerage Services (NI) Bill, which was scheduled to receive Royal Assent in March 2016. This revision incorporates a new section on the adoption of selective SuDS structures. There are currently no specific requirements set out by regulatory bodies to control the volume or frequency of runoff.

The NI Environment Agency require Water Framework Directive (WFD) assessments to be undertaken for schemes which require an Environmental Impact Statement where there is the potential for impact on the water environment, and SuDS will generally be proposed to manage the quality of surface water runoff as a result. Standing advice for Developers which was published in April 2015 states "If it is not possible to adequately manage construction or operational phase site drainage using SuDS features, consent to discharge under the terms of the Water (Northern Ireland) Order 1999 may then be required."

Any requirement for SuDS to deliver biodiversity and amenity benefits would be delivered through embedding of requirements within local area plans which, at the time of publication, are undergoing development by the newly formed regional councils.

\section{Germany}

In Germany, the regulations covering hydraulic design of urban drainage systems and flood protection requirements essentially follow the recommendations and requirements provided by European Standard EN 752. The level of flood protection required (specified in terms of flood frequency) is related to land use and type of built-up area (rural, residential, commercial area). For piped sewerage systems, maximum surcharge frequencies are also specified.

In relation to climate change and the potential increases in severe rainfall intensities and associated urban flooding events, adaptation requirements that demand more flexibile drainage solutions are still under discussion. At the same time, measures are being taken to raise awareness amongst both decision makers and the public of the residual risks posed by extreme storm events. Germany is following the specific guidelines set out in the European Flood Risk Management Directive in terms of delivering successful urban flood protection, and a joint community task force has been set up to help implement the concept of 'Pluvial Flood Risk Management (see Figure 2).

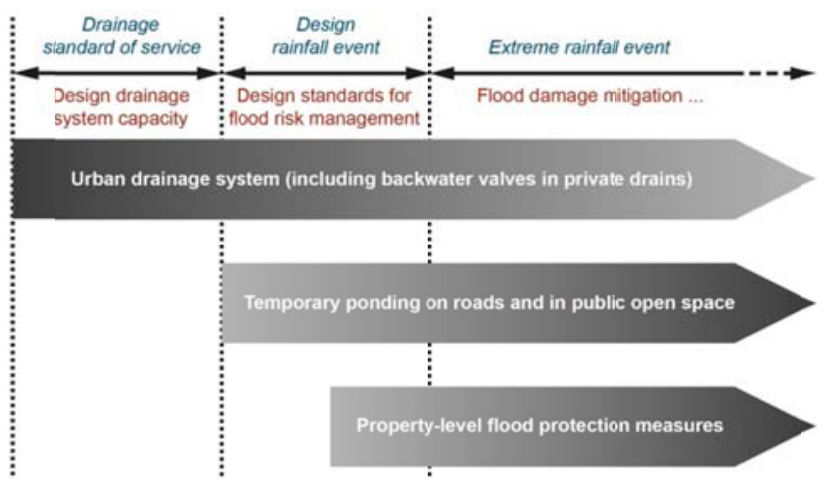

Figure 2 Objectives, elements and functions of pluvial flood risk management for urban drainage systems (according to DWA 2015a)

Based on the regulations "Guidelines for integrated urban drainage" (DWA, 2006), the concept of sourcebased stormwater management and water sensitive urban development is strongly recommended in Germany. In addition, the new German Water Act (WHG 2009) includes strict specifications related to surface runoff. The regulations DWA-A 102 (DWA, 2015b) (in preparation) will require the evaluation of wet-weatherflow in terms of its pollution load and impacts on receiving water's needs. This includes the requirements for, the type and the level of treatment for polluted surface runoff based on the risk of damaging effects on natural water bodies. 
The requirements are aimed at driving the development of systems that have the overall target of matching the water balance of developed areas with those of the undeveloped state (Figure 3). The proof of the water balance must be based on annual estimates of evaporation, infiltration and surface runoff for pre- and post-development scenarios. Coefficients have been developed to characterize different types of built-up and paved areas, depending on local hydrological data and site characteristics.

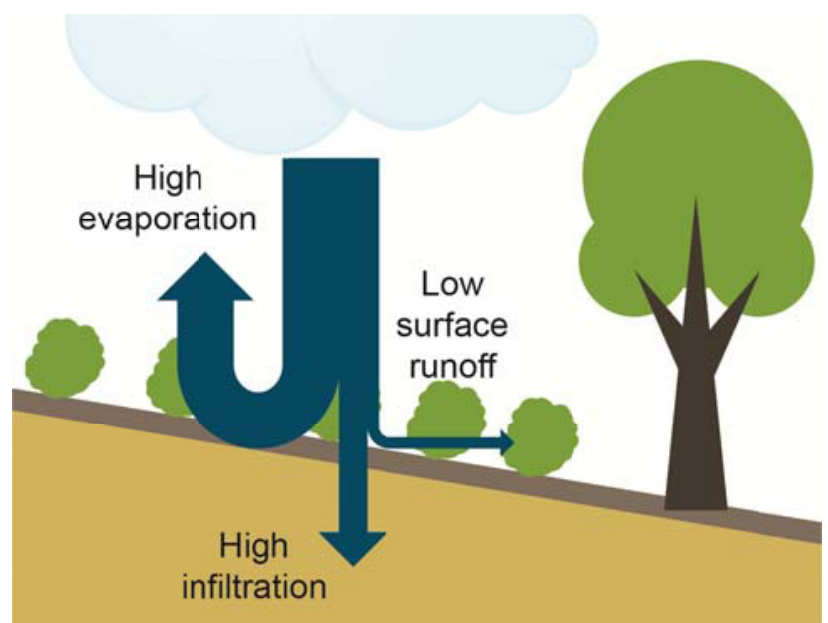

Figure 3 Local water balance of vegetated, unpaved areas as a benchmark for water sensitive drainage (DWA, 2006)

In terms of pollution control, the parameter AFS63 (i.e. particulate matter, particles $<63 \mu \mathrm{m}$ ) has been established as a major reference point. Pollution of stormwater runoff is rated in terms of the area type and use (roof area, traffic area, residential/commercial area, traffic intensity etc.) and classified into one of three load categories: minor (I), moderate (II), and heavy (III) pollution load. For areas of category II and III, treatment of surface runoff is required before discharge into surface waters. By providing numeric estimates of the likely pollution load for the parameter AFS63 for the three load categories, the required efficiency of treatment can be derived for any composition of different land uses and area type. Again, source-based measures of storrmwater treatment are favoured as the best solutions. Infiltration of stormwater is tolerated for categories I and II with restrictions to the type of infiltration facility, depending on the pollution load and the local situation.

For combined sewer systems, the existing procedure of providing storage and treatment of combined sewer flow in order to reduce combined sewer overflows, has now been adapted to take account of the new reference parameter AFS63. Long-term pollution load simulation is strongly recommended to compute the resulting pollution load and discharge to receiving waters from proposed schemes. These simulations should include the effects of combined sewer flow on the performance of the waste water treatment plant.
The regulations described are discharge-based and are complemented by regulations: related to receiving water quality criteria. These criteria are directly linked to parameters provided by the European Water Framework Directive, where biodiversity is one important aspect. In addition, temporal concentrations of harmful and toxic substances as well as minimum oxygen concentrations and abiotic criteria (stream morphology etc.) are all taken into account.

\section{France}

In France, stormwater management considerations were first introduced by the Civil Law in the $19^{\text {th }}$ century but only in relation to the responsibilities of private owners (article 640, 641 and 681 of Civil Code). In general, local authorities are responsible for stormwater management in urban areas, except for some types of roads which come under the jurisdiction of districts or national State services. Since the 1992 Water Act (Loi $\mathrm{n}^{\circ}$ 92-3 du 3 janvier 1992 sur l'eau), this responsibility includes the definition of 'drainage zones' which define (i) areas where measures have to be taken to limit soil imperviousness and stormwater flows and (ii) areas where stormwater has to be stored and treated as a result of the pollution it might cause to the receiving waters (article L2224-1 of Code Général des Collectivités Territoriales). To reinforce this role, French national law introduced (in 2006) the legal basis of what might become a dedicated stormwater utility framework.

In addition, the Water Act 1992 also introduced criteria defining whether a project that affects local water resources must go through a 'declaration' or an 'authorisation' process managed by local State services. The criteria relates to stormwater discharges and states that if the area of the proposed development site + any adjacent areas discharging runoff onto the site is (i) greater than 1 ha, then the contracting authority goes through a declarative process, and (ii) greater than 20 ha, then it goes through an authorisation process. In both cases, the contracting authority has to prove that the options for stormwater management are the best to protect water resources (including water quality, peak discharges, and runoff volumes).

French national regulations do not currently define quantitative criteria for hydraulic control but rather encourage local prescription on a case by case basis. However, practices from older technical guidelines dating back to the 1970 s remain common such as - for instance the sizing of sewer networks and stormwater management measures for a 10-year return period. To encourage local authorities and project holders to develop more integrated approaches, level of services were defined in the $2000 \mathrm{~s}$ (Certu, MEDD, 2003), to deal with a range of rainfall events (Figure 4). 


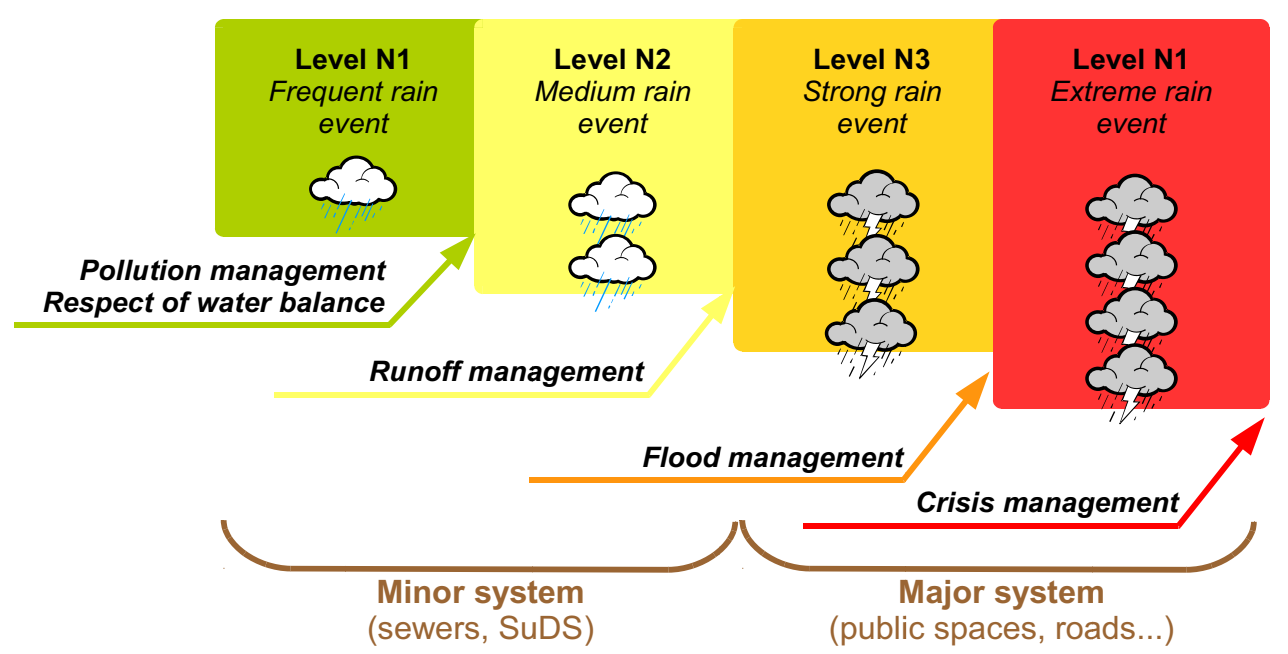

Figure 4 Graduated levels of service for stormwater management systems (translated and adapted from Certu, MEDD, 2003 andin DGALN et al., 2014).

National guidelines (MEDD, Certu, 2003; ASTEE, to be issued in 2016) do not give the return periods for different levels of service (although reference to EN752 is sometimes made), but require project designers to select appropriate standards with full knowledge of the local on-site and downstream constraints, unless any local regulations apply (see Figure 5). For instance, the City of Lille has undertaken significant work in order to specify appropriate levels of service in its city-wide stormwater management policy (LMCU, 2012).

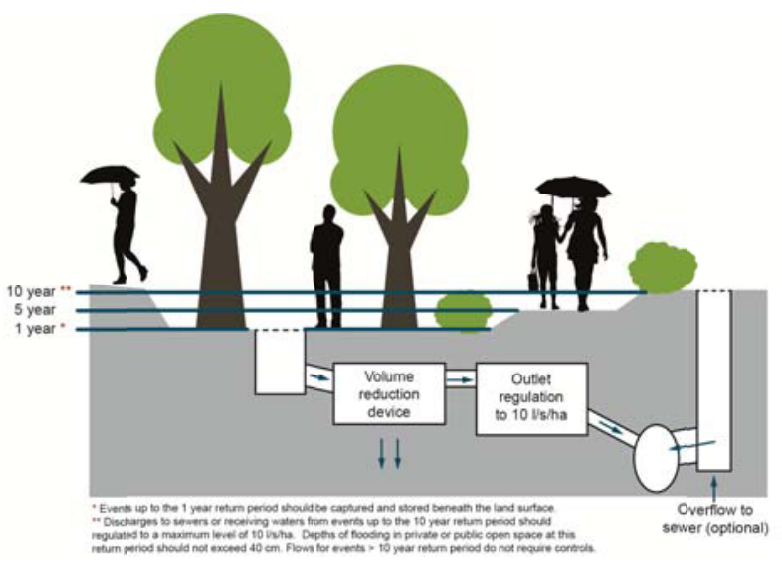

Figure 5 Demonstration of rainwater zoning specified by the City of Paris

French national regulations do not currently prioritize stormwater discharge destination. However, the government (and pioneer local authorities) have,for many years, placed significant emphasis on source control measures and - more recently - infiltration measures (Ministry of the Environnement, 2013). Specific quantitative regulations are defined by local municipalities and numerous guidelines are available. Flow limitation is a very common criterion (Petrucci, 2012; Le Nouveau et al., 2014) but the requirement to manage and prevent discharge from small rainfall events is now gaining greater attention (Nezeys, 2013, e.g in Paris and Lyon areas. Attention is also put on amenity benefits and - more recently - on the delivery of biodiversity benefits (Cerema, 2015). Rainwater harvesting (RWH) and use can now also be considered as a special 'discharge destination'. Guidelines are in progress to make the integration of RWH more formal to address the integrated level of services to be provided by drainage and stormwater management systems (Gerolin et al., 2013).

\section{USA}

Stormwater management in the United States is regulated at the local, state, and federal level. The diverse needs of different states (e.g the management of intense tropical rainfall in Houston, Texas and South Florida, compared to the strain on water resources in the arid regions of the southwest) and the various regional economic, social, and political drivers all influence whether or not individual states adopt a regulatory framework and the content of any such regulations.

Regulating both quantity and quality of runoff characteristics has led to widespread adoption of LID practices in the US. One barrier to implementation is that stormwater is generally regulated by local government, whereas combined sewer systems (CSS) (for which many of the benefits occur) are typically regulated by quasigovernmental utilities. The US Environmental Protection Agency (EPA) has strongly supported LID since its introduction at the turn of the century, but has very limited regulatory authority to compel the use of LID.

One area in which the EPA does have the ability to move practice toward LID is through Federal Permits, most significantly the Municipal Separate Storm Sewer System (MS4) permits for municipalities, universities, military bases, etc., which maintain separate storm sewer systems (i.e. do not drain to CSS). There are approximately 7500 regulated MS4 communities (and $770 \mathrm{CSS}$ ) in the US. (Capacasa, 2015). These permits apply to significant urban areas, and represent the largest number of communities that have implemented LID regulations. While the administration of a large number of MS4 programs is delegated to the states, the EPA conducts regular audits, resulting in fines for regulated communities that are deemed to be inadequately preventing polluted runoff. Another area where the EPA does have regulatory authority is for discharges to 
"Waters of the US," as defined by the Clean Water Act 1972 (CWA), for which the federal government has jurisdiction. This allows the EPA jurisdiction over Combined Sewer Overflows (CSO) and has led to a series of consent orders for the older US cities that still use combined sewer systems. In terms of requirements for hydraulic control of runoff from the site, the regulations are variable throughout the US. Most states have requirements for the detention of runoff such that post-developed peak rates are reduced to pre-developed rates. This is often required for the 2- and 10- year return periods, and in some cases for as much as the 100-year return period (MDE, 2000), although many local and regional authorities may also have more stringent requirements.

Stormwater quality control in the US is typically addressed using two mechanisms. The first is to improve the quality of the runoff, without specifically targeting volume reduction. This was the approach throughout the 1990's where the primary water quality treatment mechanisms were retention ponds for increased settling of particulate matter, and aquatic benches to facilitate vegetative uptake of dissolved nutrients. The second is commonly referred to as runoff reduction, whereby there is an expectation that a portion of the total volume of rainfall will be removed from the runoff total. The amount of runoff reduction varies widely, but is often set at the $90^{\text {th }}$ percentile rainfall, or around $25 \mathrm{~mm}$ of rainfall (MDE, 2000, CSN, 2011). The regulations in the US are often specified to achieve a certain percent removal of the pollutant of concern (e.g. total suspended solids - TSS, total phosphorous - TP, or total nitrogen - TN). Therefore, any practice that can remove a portion of the total volume is assumed to have achieved a $100 \%$ reduction of the pollutants of concern associated with that volume.

\section{China}

Over the last few years, it has been recognised in China that its rapid urbanisation has placed huge pressure on the environment and natural resources and may, eventually, be unsustainable and self-limiting. China's New Urbanisation Planning Guidance (2014-2020) (State Council of the PRC, 2014) clearly sets out that China's urbanisation must enter a new stage of quality-oriented transformation, ensuring that development does not occur at the expense of natural resources, environmental pollution and ecological degradation. The Conference Report at the 18th Communist Party of China congress (Jin, 2012) promotes a requirement for an 'ecological civilisation' concept - with the construction of 'sponge cities' as a key component.

The 'sponge city' is defined as development that prioritises the natural attenuation, infiltration and purification of stormwater runoff - using systems that are resilient and adaptable, that absorb (and can then release) water for use and in so doing reduce flood risk, protect water resources and enhance ecological systems. The terminology used to describe this is 'Low Impact Development (LID)' and the design objectives for such developments are presented in Figure 6.

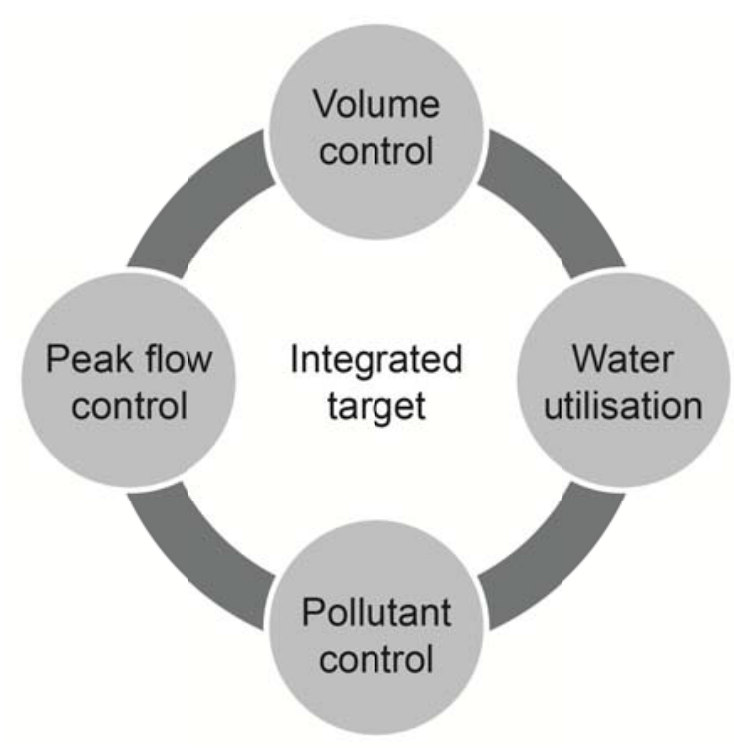

Figure 6 Diagram showing China's Low Impact Development (LID) Control Objectives

New cities are now required to consider LID at all stages in their development - integrating stormwater control with public and private space design, architectural building design, transportation networks, drainage and water supply infrastructure. Regional planning controls must set LID objectives and criteria that reflect local objectives, hydrology, weather, land use conditions etc and both technical and economic optimisation is recommended to ensure that solutions provide 'efficient investment' for the region.

Sponge city projects need to comply with the "Sponge City Construction Technical Guidance" (Ministry of Housing, PRC 2014) which specifies the following key objectives (see also Figure 7):

- Total Annual Runoff Volume Control Rate - the proportion of the total rainfall volume that should be infiltrated, used or otherwise retained on site. This is the primary criteria, with a target of $60-90 \%$, specified regionally.

- Peak Flow Control - requiring compliance with Outdoor Drainage Design Specifications (GB50014) (Mouhurd, 2006) for flood risk management and drainage system standard of service design.

- Rainwater Harvesting - the proportion of rainfall that should be harvested to meet local water resource needs.

- Runoff Pollution Control - LID delivery of suspended solids removal rates of $40-60 \%$.

Supporting objectives include the ecological remediation of land adjacent to natural water bodies, the maintenance and protection of stable long term groundwater levels, and the alleviation of potential negative urban heat island effects resulting from the development. 

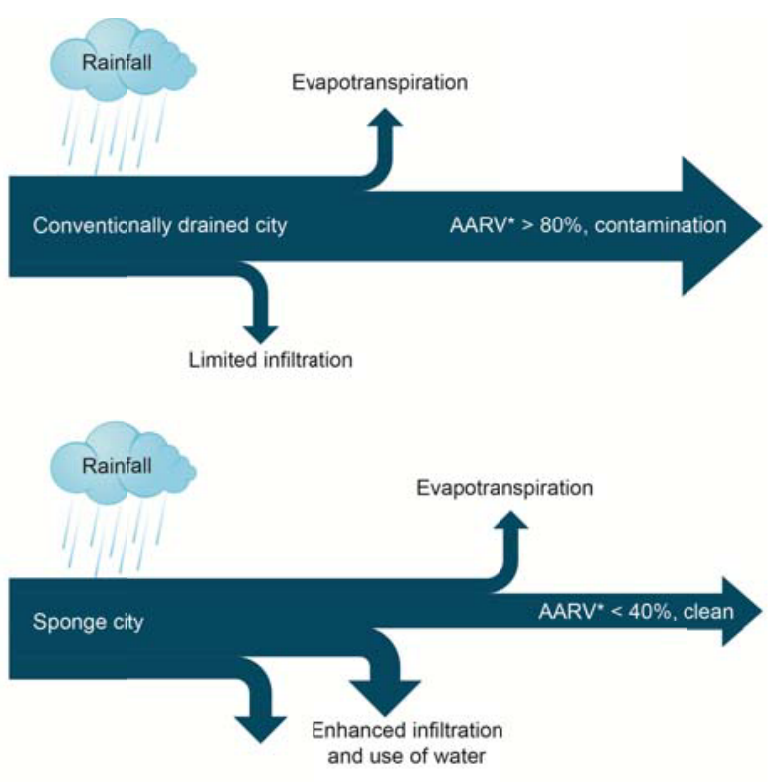

Figure 7 Diagram showing the LID hydraulic control objectives

\section{Discussion}

This paper provides a summary of how approaches to surface water management are shifting internationally, by reference to strategies, policies and regulations in each of the devolved administrations in the UK, in France and
Germany, and in China and across the USA.

In all countries, the management of runoff to meet certain environmental and social objectives is now recommended and in some countries it is required by regulation; however the specific objectives vary widely. This variation may be due to specific environmental stresses in the country or region, or may be a function of the way in which regulations or policies have developed through time and the priorities of the organisations that have responsibility for drainage or its regulation.

Mitigating the impact of development on flood risk in the receiving waterbody and the effective management of flood risks associated with the drainage system is a universal goal; with the protection of the chemical and biological quality being more variable in its importance and requirements. In Scotland, the USA and Germany the focus for SuDS/BMPs/LID has very much been on supporting water quality protection. In contrast, in England, the emphasis in the official SuDS guidance is primarily on hydraulic control for flood protection.

The management of large rainfall events is key to flood risk management; the management of smaller events supports the hydrological and ecological health of both the groundwater and surface water catchments. The concept of volume control by preventing runoff from the site (retaining on site, infiltrating, collecting runoff for non-potable use etc.) from a specified depth of rainfall is gaining momentum - with requirements set in regions of France, Germany, USA, China, England (only in

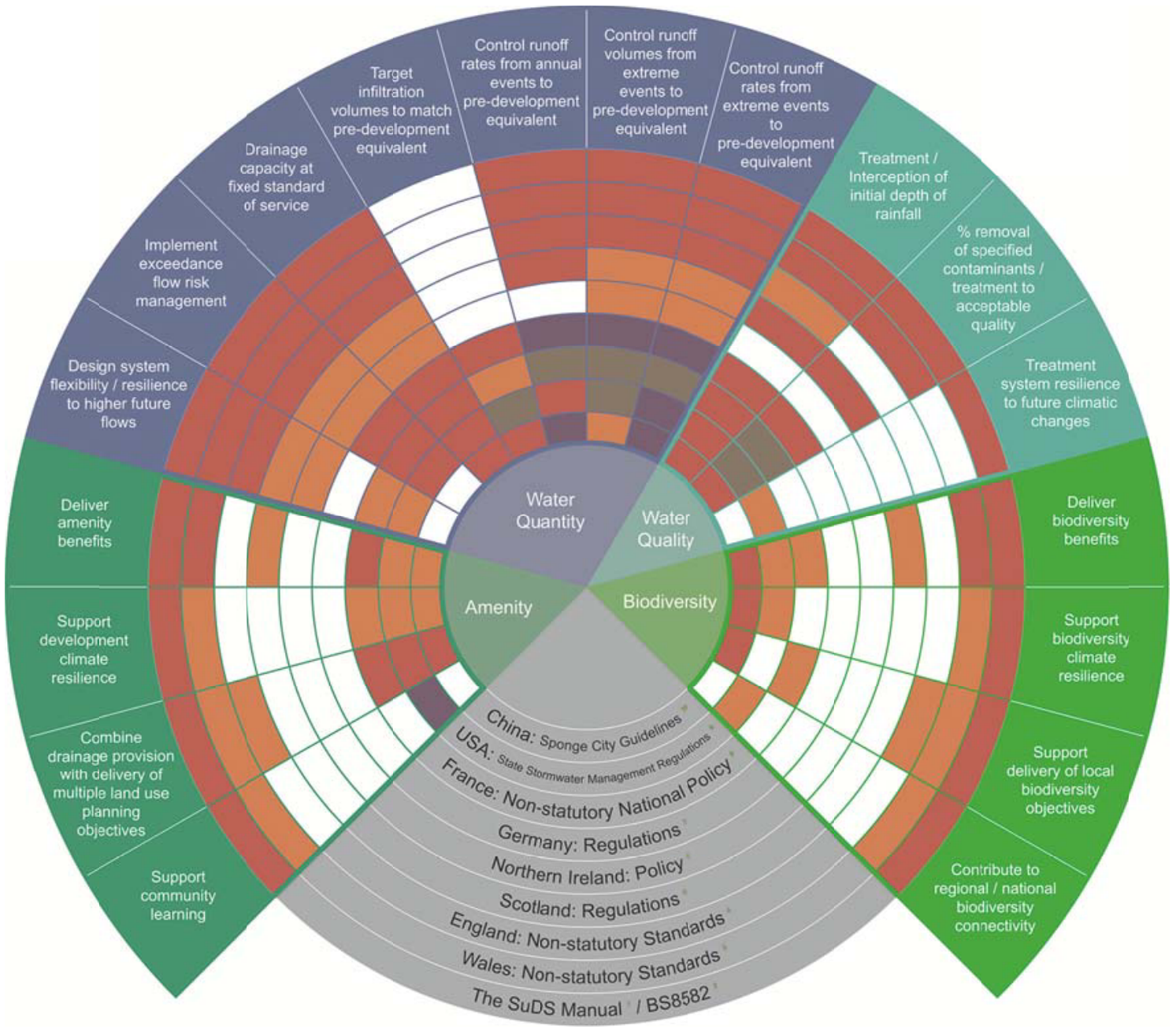

Figure 8 Generic comparison of the criteria 
guidance) and Wales (in their non-statutory Standards). A criterion for matching average annual runoff volumes for pre- and post-development states (Germany, China) reflects an awareness of the benefits of trying to replicate the natural hydrological response from sites across all scales of rainfall. The new UK SuDS Manual prioritises infiltration and use of runoff wherever appropriate, and sets as standard the retention of $5 \mathrm{~mm}$ of the majority of rainfall events on site ('Interception') and limiting runoff volumes for the 1:100 year, 6 hour event to the predevelopment equivalent. A generic comparison of the criteria is provided in Figure 8.

\section{Conclusions}

Drainage criteria are continuing to evolve, with a greater focus on their integration within a more holistic approach to environmental management. If effectively implemented, regulated and monitored, these steps should bring about significant benefits in terms of mitigating the impact of development on the water environment, reducing urban flood risk, and securing greater social and environmental value from surface water - a valuable and an increasingly scarce resource for many.

Aiming for a more natural runoff response from our developed areas is laudable and legislation and regulation aimed at delivering this requirement will support urban planners in promoting development that has higher levels of 'permeability' The resultant intrinsic properties of such development should deliver drainage systems that are more adaptable to our changing climate, should help provide access to an alternative supply of non-potable water where required, and should help improve the resilience and liveability of our urban areas. Developing and supporting suitable economic drivers for these changes is, however, still highly challenging. Green space is not currently a financial commodity, and developing ways of aligning long-term positive societal benefits with short-term business interests are not often obvious.

However, from a technical perspective at least, learning from others is crucial. Reviewing the methods adopted by other countries provides us with an opportunity to explore how we can use more sustainable surface water management measures to most efficiently protect our natural environment, mitigate the impacts of development on natural hazards, and support future urban quality of life. In the UK, decision makers should consider the potential benefits of a more volumetric approach to runoff control. Lessons also need to be learnt from cities such as Copenhagen regarding future city design strategies to deliver resilience to the types of extreme intense rainfall events that have caused widespread damage (e.g. Hull, 2007, Copenhagen, 2011, Germany, 2013) and are likely to become increasingly common into the future. Integration is crucial, not only in delivering on environmental objectives, but across disciplines - with drainage design meshing seamlessly with the planning and design of the built environment, and the landscaping of our urban space.

\section{References}

Ashley R, Walker L, D’Arcy B et al (2015) UK sustainable drainage systems: past, present and future. Proceedings of the Institution of Civil Engineers - Civil Engineering 168(3): 125-130

ASTEE (to be issued in 2016). Mémento pour la conception et le dimensionnement des systèmes de gestion des eaux pluviales et de collecte des eaux usées, technical guidance.

Capacasa, J. (2015), Urban Stormwater: A Perfect Storm for Change, CBP3 Sustainable Stormwater Infrastructure Summit, 7 December 2015, Philadelphia, USA.

Cerema (2015). Milieux humides et aménagement urbain.Dix expériences innovantes, recueil d'expériences.

Certu, Ministère de l'Ecologie et de Développement Durable (MEDD) (2003). La ville et son assainissement : principes, méthodes et outils pour une meilleure intégration dans le cycle de l'eau. Ed. Certu, CD-rom.

Chesapeake Stormwater Network (CSN) (2011), Technical Support for the Bay-Wide Runoff Reduction Method (v.2.0), 2011, Ellicot City, Maryland, USA.

Department for Communities and Local Government (2014) Written Statement (HCWS161)

Department for Communities and Local Government (2015) National Planning Practice Guidance, Updated April 2015

Department for Environment, Food and Rural Affairs (2015) Sustainable Drainage Systems - Nonstatutory technical standards for sustainable drainage systems, March 2015.

Department of the Environment, Northern Ireland (DoE NI) (2014) Revised Planning Policy Statement 15: "Planning and Flood Risk". PPS 15. Belfast, September 2014.

DGALN (2014), Cerema, Agences de ltils pour uneProcN, Cerema, Agences de ltils pour une me des projets $d$, Agences de ltils pour une meilleure intégration dans le cycle de l'eau.n des projets $d$, A. Repprojets d, A.ences de ltils pour une meilleure int, on-line.

DWA (2006): Guidelines for integrated urban drainage (Leitlinien der Integralen Siedlungsentwässerung), DWA-Regelwerk, Arbeitsblatt A 100, Hennef, Dezember 2006.

DWA (2015a): Risk Management in Urban Flood Precaution - Analysis of Flood Hazards and Damae Potentials to Evaluate Flood Risks (Risikomanagement in der kommunalen Überflutungsvorsorge - Analyse von Überflutungsgefährdungen und Schadenspotenzialen zur Bwertung von Überflutungsrisiken). Technical Bulletin DWA-M 119 ('Merkblatt'), DWA-Regelwerk, Hennef (Draft July 2015).

DWA (2015b): Wet weather flow in urban areas emission-based regulations for stormwater management. (Niederschlagsbedingte Siedlungsabflüsse

Emissionsbezogene Regelungen zum Umgang mit Regenwetterabflüssen). DWA-Regelwerk, Arbeitsblatt A 102 (in preparation).

Gerolin A., Le Nouveau N., de Gouvello B. (2013). Rainwater harvesting for stormwater management: 
example-based typology and current approaches for evaluation to question French practices, Novatech 2013

Jin T, Hu (2012), Conference Report, The 18th National Congress of the Communist Party of China, Beijing, Nov. 8,2012

Lasoo (2015) Non-statutory technical standards for sustainable drainage: practice guidance (lasoo.org.uk)

Le Nouveau N., Deroubaix J-F., Gerolin A., Kerloc'h B., Ramier D., Gradel O., Ruperd Y., Ménétrieux C., Le Mitouard E., Correa E., Dulac E., Hautbois O., Ganne M., Soyer M., Tardivo B. (2014). Towards territorial policies for managing urban stormwater: analysis of regulation of twenty local authorities in France, IWA World Water Congress and Exhibition, 21-26 September 2014, Lisbon

Lille Métropole Communauté Urbaine (LMCU) (2012). Guide de gestion durable des eaux pluviales. Fiches techniques, on-line.

Maryland Department of the Environment (MDE), Maryland Stormwater Design Manual, 2000 (Revised May 2009), Baltimore, Maryland, USA.

Ministry of Housing and Urban-Rural Development - the People's Republic of China (2014) Technical Guidelines for the Construction of Sponge City Construction of Stormwater System Based on Low Impact Development (Trial), October 2014.

Ministry of the Environment (2013). Internet portal on stormwater management :

http://assainissement.developpement-

durable.gouv.fr/pluvial.php

Nezeys A. (2013). A Rainwater Zoning for Paris: reinstate the urban stormwater into the great water cycle, Novatech 2013

Northern Virginia Planning District Commission, Northern Virginia BMP Handbook: A Guide to Planning and Designing Best Management Practices in Northern Virginia, 6 November 1992, Annandale, Virginia, USA

Petrucci G. (2012). La diffusion du contrr Paris: reinstate the urban stormwater into the great water cycle,enty local authorities in France,ur $\mathrm{pHD}$ in planning. Paris : Université Paris-Est, 2012, 329 p.

Pitt, M (2008) Learning lessons from the 2007 floods (The Pitt Review), June 2008.

SEPA (2014) WAT-RM-08 Regulatory Method for Sustainable Urban Drainage Systems (SuDS or SuD Systems), SEPA, v5.2, August 2014.

State Council of the P.R.C, (2014), China's New Urbanisation Planning Guidance (2014-2020), Beijing, 2014

SUDS Working Party (SUDSWP) (2016) Water Assessment and Drainage Assessment Guide.

Welsh Government (2016) Recommended nonstatutory standards for sustainable drainage (SuDS) in Wales - designing, constructing, operating and maintaining surface water drainage systems, January 2016.

Welsh Government Water Strategy (2015)

Woods Ballard, B, Wilson, S, Udale-Clarke, H, Illman, S, Scott, T, Ashley, R and Kellagher, R (2015) The SuDS Manual, C753, CIRIA, London, UK. http://www.ciria.org/Resources/Free publications/SuDS $\underline{\text { manual C753.aspx }}$
WRc (2015) Sewers for Scotland, 3rd Edition.

WRc (2010 Sewers for Adoption Northern Ireland

Standards and Statutes

BS 8582:2013 Code of practice for surface water management for development sites.

BS 8515(2009)+A1(2013): Rainwater harvesting systems. Code of practice

BS EN 752: 2008Drain and sewer systems outside buildings

Drainage (Northern Ireland) Order 1973.

Directive 2000/60/EC of the European Parliament and of the Council establishing a framework for the Community action in the field of water policy

Directive 2007/60/EC of the Europeann Parliament and of the Council on the assessment and management of flood risks

EN 752 Drain and Sewer Systems outside buildings (CEN, 2008)

Flood and Water Management Act 2010

French Water Act (Loi n 92-3 du 3 janvier 1992 sur l'eau

German Water Act (WHG 2009)

Sewerage (Scotland) Act 1968

USA Clean Water Act 1972

Water (Northern Ireland) Order 1999

Water and Sewerage Services (Northern Ireland) Order 2006

Water Environment and Water Services (Scotland) Act 2003.

Water Environment (Controlled Activities) (Scotland) Regulations 2011.

Water (Scotland) Act 1980.

Well-being of Future Generations (Wales) Act 2015. 